\title{
Analysis on Major Factors Affecting Intention Level to Renew Maintenance Contract -Focused on Foreign ERP Software
}

\author{
Jeong Keun Park ${ }^{1}$, Kyeong Seok Han ${ }^{2 *}$ and Seong Ho Kim ${ }^{3}$ \\ ${ }^{1}$ PhD, Department of IT Policy Management, Soongsil University, Seoul \\ $2^{2}$ Professor of MIS, School of Business Administration, Soongsil University, Seoul \\ ${ }^{3}$ PhD, Department of IT Policy Management, Soongsil University, Seoul \\ ${ }^{1}$ Pjkjh11@gmail.com, ${ }^{2}$ kshan@ssu.ac.kr, ${ }^{3}$ generalksh@korea.kr
}

\begin{abstract}
Many companies are introducing and using ERP software as part of sustainable innovative strategy and competitiveness improvement through internal resource management efficiency and visibility. It is studied which the major factor affects the intention level to renew ERP software maintenance service contract of the companies using ERP. Through precedent research, performance risk, time delay risk, and psychological anxiety risks are extracted as properties of push factors based on the theory of migration, reliability, responsiveness, and assurance of SERVQUAL are extracted as properties of pull factors, and the price level is extracted as properties of mooring factors. A proposal analysis model of major factors affecting intention level to renew maintenance service through perceived usefulness of maintenance service is suggested This study has meaningful that the major factor affecting intention level to renew maintenance service could understand and an empirical foundation for future maintenance service program, service enhancement, and maintenance service business model development of ERP vender is provided based on the result of the study.
\end{abstract}

Keywords: PPM Model, TAM Model, Servqual, Perceived Risk, ERP Software, Maintenance, Maintenance contract, Renewal, Renew Maintenance Contract, Audit

\section{Introduction}

Enterprise has introduced ERP package software as the means of gaining a competitive advantage and sustainability in the competitive market circumstances where the industrial environment all over the world is fast changing thanks to IT development and the fourth industrial revolution. ERP has been used as an efficient tool to business management activities such as securing company management efficiency, visibility, and decision making timeliness by allowing all the company information to be integrated and managed [1]. The company purchased an ERP solution has its IT department actively support business and drive business innovation by using various technical support services provided by ERP provider such as patch for fixing bug of ERP source code itself, software upgrade for improving function and performance, upper version, technical support service to solving technical problems happening during ERP system operation, efficient administration notice of the ERP system, and ERP system diagnosis through maintenance service contract. It is estimated that the investment in ERP-related support service will constantly increase by 2020, and thus ERP software maintenance has been focused in terms of enterprise's cost retrenchment and ERP vender's gain generation. The enterprise using ERP S/W grumble about value against maintenance charge paid yearly in the circumstance that the ERP maintenance market is constantly growing not only in the local but also all over the world.

Received (December 15, 2017), Review Result (March 8, 2018), Accepted (March 12, 2018)

* Corresponding Author 
However, almost all the enterprise are continuously renew their maintenance contract with ERP provider. This study has the objective of improving end user's satisfaction with provider's maintenance service through enhancement of provider's maintenance service in practical aspect as well as theoretical aspect, and assisting two parties' continuous virtuous cycle growth by carrying out an empirical analysis of factors affecting enterprise' intention level to renew ERP maintenance service contract focusing on ERP maintenance contact ignored in previous research in this aspect.

\section{Theoretical Background}

\subsection{Definition of ERP}

ERP (Enterprise Resource Planning) is an information system integrally managing information of all the resources in a enterprise, and flowing information between all the departments in the organization like a production, procurement, human resource, marketing, support, development and sales in real-time through a computer network in the enterprise connected like a spider's thread. Generally, ERP is a technology for integrally managing work processes such as manufacturing, logistics distribution, HR, and account management, and is an enterprise-wise integral solution which is a business strategic approach for combining information technology and business instead of simple information technological approach [11]. Integrating existing definition of ERP, ERP is defined as an "integral resource management system linking functions and supporting integral management beyond functions and regions of physically separated organizations in accordance with the situation that functions in each field are separated according to work diversification strategy of a company or group" through the business concept and a high-tech system for a plan and management optimizing use of all of company's business resources-people, equipment, materials, information, time, service, and the like used in business activity in order to maximize the company's profit $[12,14]$.

\subsection{Software Maintenance}

Software maintenance means an activity of delivering software-related product and source code in order to fix error, update work process, or reflect administration environmental change after the software is provided to an enterprise. Software maintenance is an activity executed after the manufactured software product is delivered to an enterprise, and means correction and technical support service of the software product. In other words, software maintenance activity means a series of activities of extending software lifespan by completely understanding currently operated software functions, accurately analyzing enterprise's requirements for improvement, testing functions to be partially corrected, removing errors and then changing programs. Maintenance in software engineering is a series of activities is a final step of a software life cycle process of removing errors, correcting things as user requested, and improving function and performance $[2,13]$. Which means that software maintenance activity is consistently performed for a software lifecycle while raising software maturity and prolong life. Likewise, software maintenance corrects or removes bugs and errors found before and adds new functions to respond to enterprise's request. Since new issues additionally happen in this process and software should respond to enterprise's request for update according to regulation update and function improvement, it is characterized that needs for software maintenance are repeated.

\subsection{Migration Theory}

Migration Theory explains a person's movement between two places for a certain period, and explains a person's movement through push factor and pull factor. The push factor is a factor of making a person move from an original residence to new residence, and the pull factor is a new residence-related factor of leading a person to a new residence [3]. There 
are negative push factors driving people move from a territory where they originally live, and positive pull factors of pulling people to a destination of migration. These pull-push factors interact with mooring factors which is a people's personal and social factor driving people stay in an original territory or driving migration to a new territory. Considered through pull-push paradigm still used currently as a major frame of migration-related researches, the first residence has a factor or making people move from the place, and a new residence has a factor of attracting people to move in [4]. According to recent research, migration is determined according to macroscopic recognition affected by pull-push factors and microscopic recognition affected by mooring factors. Accordingly, it is insisted that a positive factor of the destination of migration attracting people, a negative factor of original residence, and a personal characteristic factor making determination of migration easy or interfering determination should be integrally measured to finally make a decision of migration.

\subsection{Technology Acceptance Model}

Technology Acceptance Model (TAM) is developed as a theoretical frame for figuring out factors affecting organization member's acceptance process related to information technology introduced to improve work performance of the organization [5]. The technology acceptance model focuses on organization member's faith to specific innovation, a positive or negative attitude of evaluation, the causal relation between intention to use and actual use, and external factors affecting acceptance process [6]. Considering the major concept shown in this study, there are perceived ease of use and perceived usefulness. The perceived ease of use means the level of "trust that it would not take much effort to use a specific object". The perceived usefulness means "individual faith that the individual performance can be increased by using a specific object". The technology acceptance model shows that user's perceived ease of use and perceived usefulness affect attitude toward using a system, and intention of the action has a valid effect to actual system use.

\section{Research Design}

\subsection{Research Model}

This study suggested a proposal analysis model as Figure 1 by introducing push factors, pull factors, and mooring factors which are proposed in Migration Theory to the proposal analysis factors as described above. A performance risk, a time delay risk, and a psychological anxiety are set as sub-variables of push factors, and reliability, experienced responsiveness, and assurance are set as sub-variables of pull factors. A price level is set as a sub-variable of mooring factors. In addition, a perceived usefulness of maintenance service is set as a parameter, and an intention level to renew maintenance contract as a dependent variable, and the relation between those variables is verified. 


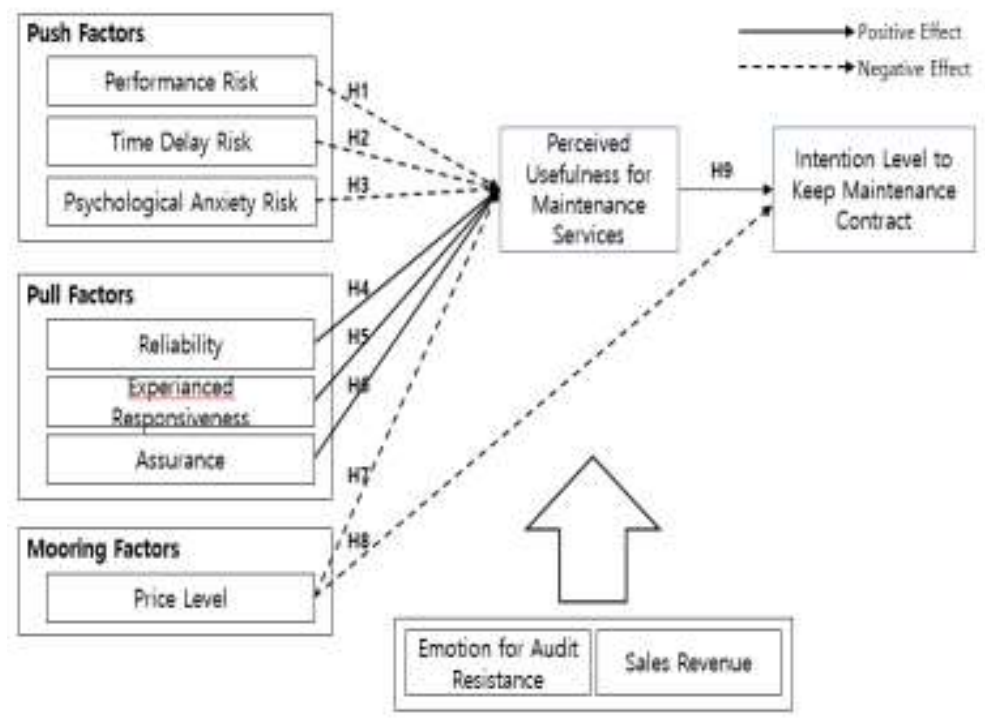

Figure 1. Research Model

\subsection{Hypothesis about Push Factor Properties and Perceived Usefulness of Maintenance Service}

After suggesting a result risk, a performance risk, a financial risk, a personal information security risk, a time risk, a physical risk, psychological risk, and the like as a perceived risk which is properties of push factors, the research result that perceived risk negatively affects perceived usefulness is suggested [17]. The research result that in case of consumers who have purchasing experience, perceived risk negatively affects perceived usefulness, but in case of consumers who do not have purchasing experience, perceived risk does not affect perceived usefulness [7]. Based on result of previous research, a hypothesis that the performance risk, time delay risk, and psychological risk which are perceived risks of push factors negatively affect perceived usefulness of maintenance service was established.

\subsection{Hypothesis about Pull Factor Properties and Perceived Usefulness of Maintenance Service}

The service quality of pull factors is a measurement and evaluation list related to a person providing a service in an information system success model. Since various types of services with variables related to service quality provided by an information system department are provided, service quality has an important part of information system success indicator $[15,16]$. In addition, if the service quality is ignored in information system evaluation, the possibility of failure to effectively understanding the entire information system, and thus service quality should be sufficiently considered [8]. Hence, in this study, it is hypothesized that pull factors will positively influence perceived usefulness of maintenance services.

\subsection{Hypothesis about Mooring Factor Properties and Perceived Usefulness of Maintenance Service}

The research result that if a user perceives a level of prices according to a correlation between a price level of mooring factors and perceived usefulness, the user will measure the usefulness of trade higher is suggested [10]. Furthermore, it was proved that the price level a user perceives is tightly related to perceived usefulness. And it is explained that the price level directly influences perceived usefulness. Hence, this study hypothesized that mooring factors will negatively influence perceived usefulness of maintenance service. 


\subsection{Hypothesis about Perceived Usefulness of Maintenance Service and Intention Level to Keep Maintenance Contract}

It was proved that perceived, usefulness directly and indirectly, affects intention of continuous use like existing researches on technology acceptance model. It was found that perceived usefulness positively affects intention of keeping using service [9]. It was proved that perceived usefulness of the system has the greatest influence. Furthermore, it was discovered that perceived usefulness influence intention of keeping using a service. A research on the intention of keeping using a service proved that the perceived usefulness influence intention of constantly use. Thus, this study hypothesized that perceived usefulness of maintenance service positively influence the intention level to keep maintenance service contract.

\section{Empirical Analysis}

\subsection{Data Collection and Population Statistics}

This study conducted a survey 1,123 employees of enterprise using foreign-made ERP software, professional IT enterprise, ERP business partners, and ERP venders for 2 months from January to March 2017, and collected 240 responses (21.4\%), and used 210 responses except unreliable respondents through data analysis. The results are described in Table 1.

Table 1. Demographic Data

\begin{tabular}{|l|l|l|l|}
\hline \multicolumn{2}{|c|}{ Category } & \multicolumn{1}{|c|}{ Freq } & \multicolumn{1}{c|}{$\%$} \\
\hline \multirow{4}{*}{ Gender } & Male & 177 & $84.3 \%$ \\
\cline { 2 - 4 } & Female & 33 & $15.7 \%$ \\
\hline \multirow{5}{*}{ Age } & 20 years & 2 & $1.0 \%$ \\
\cline { 2 - 4 } & 30 years & 58 & $27.6 \%$ \\
\cline { 2 - 4 } & 40 years & 102 & $48.6 \%$ \\
\cline { 2 - 4 } & 50 years & 44 & $21.0 \%$ \\
\cline { 2 - 4 } & 60 years $<$ & 4 & $1.9 \%$ \\
\hline \multirow{4}{*}{ position } & Staff & 26 & $12.4 \%$ \\
\cline { 2 - 4 } & Manager & 87 & $41.4 \%$ \\
\cline { 2 - 4 } & Senior manager & 50 & $23.8 \%$ \\
\cline { 2 - 4 } & C Level & 47 & $22.4 \%$ \\
\hline \multirow{4}{*}{ Working } & $<1 \sim 5$ years & 9 & $4.3 \%$ \\
\cline { 2 - 4 } & $<5 \sim 10$ years & 23 & $11.0 \%$ \\
\cline { 2 - 4 } & $<10 \sim 15$ years & 45 & $21.4 \%$ \\
\cline { 2 - 4 } & $<15 \sim 20$ years & 57 & $27.1 \%$ \\
\cline { 2 - 4 } & 20 years < & 76 & $36.2 \%$ \\
\hline
\end{tabular}

\subsection{Exploratory Factor Analysis and Reliability Analysis}

In order to fitting test of the research model, validity analysis and reliability analysis were conducted. The feasibility is a concept representing how accurately the concept to be measured was measured. This study selected construct validity focusing on whether the abstract concept was actually measured properly through a measurement tool which means whether the dispersion of measured value was made by a change in concept, and exploratory factor analysis was performed to construct validity. In this study, a Cronbach's Alpha was used to test the internal consistency of variables, and the 
reliability was evaluated based on the standards that if the value of Cronbach's Alpha is 0.7 or more, the measure is reliable. The results of exploratory factor analysis and reliability analysis is described in Table 2 . The reliability analysis was conducted and it was analyzed that the factor loading of analysis result was 0.5 or more and it is analyzed that there is validity. The value of Cronbach's Alpha was 0.7 or more. Thus, there is no issue with reliability.

Table 2. The Result of Validity, Reliability Test of EFAl

\begin{tabular}{|c|c|c|c|c|}
\hline $\begin{array}{l}\text { Construct } \\
\text { Name }\end{array}$ & Variable & $\begin{array}{l}\text { Number of } \\
\text { items for } \\
\text { analysis }\end{array}$ & $\begin{array}{l}\text { Construct } \\
\text { Validity }\end{array}$ & $\begin{array}{l}\text { Cronbach's } \\
\text { alpha }\end{array}$ \\
\hline \multirow{5}{*}{$\begin{array}{l}\text { Performance } \\
\text { Risk }\end{array}$} & \multirow{5}{*}{$\mathrm{PE}$} & \multirow{5}{*}{5} & .752 & \multirow{5}{*}{0.916} \\
\hline & & & .794 & \\
\hline & & & 861 & \\
\hline & & & .767 & \\
\hline & & & 786 & \\
\hline \multirow{3}{*}{$\begin{array}{l}\text { Time } \\
\text { Delay Risk }\end{array}$} & \multirow{3}{*}{ TI } & \multirow{3}{*}{3} & 857 & \multirow{3}{*}{0.900} \\
\hline & & & .840 & \\
\hline & & & .811 & \\
\hline \multirow{4}{*}{$\begin{array}{l}\text { Psychological } \\
\text { Anxiety Risk }\end{array}$} & \multirow{4}{*}{ PS } & \multirow{4}{*}{4} & .910 & \multirow{4}{*}{0.950} \\
\hline & & & .940 & \\
\hline & & & 914 & \\
\hline & & & .922 & \\
\hline \multirow{5}{*}{ Reliability } & \multirow{5}{*}{$\mathrm{RE}$} & \multirow{5}{*}{5} & .841 & \multirow{5}{*}{0.936} \\
\hline & & & 856 & \\
\hline & & & 841 & \\
\hline & & & 840 & \\
\hline & & & 862 & \\
\hline \multirow{3}{*}{$\begin{array}{l}\text { experienced } \\
\text { Responsiveness }\end{array}$} & \multirow{3}{*}{ EX } & \multirow{3}{*}{3} & 672 & \multirow{3}{*}{0.912} \\
\hline & & & 686 & \\
\hline & & & .725 & \\
\hline \multirow{5}{*}{ Assurance } & \multirow{5}{*}{ AS } & \multirow{5}{*}{5} & .706 & \multirow{5}{*}{0.911} \\
\hline & & & 664 & \\
\hline & & & 651 & \\
\hline & & & .780 & \\
\hline & & & 691 & \\
\hline \multirow{3}{*}{ Price Level } & \multirow{3}{*}{ PR } & \multirow{3}{*}{3} & .938 & \multirow{3}{*}{0.947} \\
\hline & & & 944 & \\
\hline & & & 931 & \\
\hline \multirow{4}{*}{$\begin{array}{l}\text { Perceived } \\
\text { Usefulness for } \\
\text { Maintenance } \\
\text { Services }\end{array}$} & & & 804 & \\
\hline & US & 4 & 815 & 0936 \\
\hline & & & 802 & \\
\hline & & & .010 & \\
\hline Intention Level to & & & .745 & \\
\hline $\begin{array}{l}\text { Keep } \\
\text { Maintenance }\end{array}$ & IN & 4 & $\begin{array}{l}.813 \\
707\end{array}$ & 0.947 \\
\hline Contract & & & 730 & \\
\hline
\end{tabular}




\subsection{Confirmatory Factor Analysis}

Confirmatory factor analysis (CFA) which can derive more precise result compared to exploratory factor analysis (EFA) in terms of reliability, validity, and unidimensionality is performed in the state that relation between variables are present on the basis of theoretical purpose, and is a statistical method used for the purpose of verifying validity test of a measure and exploratory factor analysis model. A confirmatory factor analysis targeting lists removed by using exploratory factor analysis was conducted. Considering the removed question lists, list no 1 and 2 of time delay risk, list no 4 and 5 of experienced responsiveness, and list no1 and 2 of price level were removed. As it was determined that the fitting of measurement model is good, convergent validity test and construct reliability were conducted for the finally selected analysis list based on the result of confirmatory factor analysis. It was insisted that if the standardized regression weight is 0.7 or more, it is ideal, and the construct reliability measuring internal consistency of indicator should be also 0.7 or more for the measure and reliability to be valid, and the average variance extracted value which is variance which can be explained by the indicator in terms of constructs should be 0.5 or more for the convergent validity to be secured.

Table 3. Convergent Validity Analysis

\begin{tabular}{|c|c|c|c|c|c|c|}
\hline Variable & Items & $\begin{array}{c}\text { Std. } \\
\text { Weights }\end{array}$ & C.R & $\mathbf{P}$ & CR & AVE \\
\hline \multirow{5}{*}{ PE } & 1 & 0.808 & & & \multirow{5}{*}{0.879} & \multirow{5}{*}{0.594} \\
\hline & 2 & 0.877 & 15.003 & $* * *$ & & \\
\hline & 3 & 0.857 & 14.505 & $* * *$ & & \\
\hline & 4 & 0.758 & 12.249 & $* * *$ & & \\
\hline & 5 & 0.848 & 14.301 & $* * *$ & & \\
\hline \multirow{3}{*}{ TI } & 3 & 0.909 & & & \multirow{3}{*}{0.825} & \multirow{3}{*}{0.613} \\
\hline & 4 & 0.948 & 20.732 & $* * *$ & & \\
\hline & 5 & 0.758 & 14.133 & $* * *$ & & \\
\hline \multirow{4}{*}{ PS } & 2 & 0.916 & & & \multirow{4}{*}{0.915} & \multirow{4}{*}{0.729} \\
\hline & 3 & 0.923 & 22.64 & $* * *$ & & \\
\hline & 4 & 0.876 & 19.725 & $* * *$ & & \\
\hline & 5 & 0.919 & 22.414 & $* * *$ & & \\
\hline \multirow{5}{*}{$\mathbf{R E}$} & 1 & 0.813 & & & \multirow{5}{*}{0.886} & \multirow{5}{*}{0.608} \\
\hline & 2 & 0.828 & 14.136 & $* * *$ & & \\
\hline & 3 & 0.846 & 14.594 & $* * *$ & & \\
\hline & 4 & 0.91 & 16.337 & $* * *$ & & \\
\hline & 5 & 0.912 & 16.38 & $* * *$ & & \\
\hline \multirow{3}{*}{$\mathbf{E X}$} & 1 & 0.847 & & & \multirow{3}{*}{0.870} & \multirow{3}{*}{0.637} \\
\hline & 2 & 0.908 & 17.127 & $* * *$ & & \\
\hline & 3 & 0.89 & 16.612 & $* * *$ & & \\
\hline \multirow{5}{*}{$\mathbf{A S}$} & 1 & 0.882 & & & \multirow{5}{*}{0.897} & \multirow{5}{*}{0.637} \\
\hline & 2 & 0.88 & 17.953 & $* * *$ & & \\
\hline & 3 & 0.656 & 10.95 & $* * *$ & & \\
\hline & 4 & 0.841 & 16.418 & $* * *$ & & \\
\hline & 5 & 0.859 & 17.107 & $* * *$ & & \\
\hline
\end{tabular}




\begin{tabular}{|c|c|c|c|c|c|c|}
\hline \multirow{3}{*}{ PR } & 2 & 0.912 & & & \multirow{3}{*}{0.832} & \multirow{3}{*}{0.623} \\
\hline & 4 & 0.946 & 23.711 & $* * *$ & & \\
\hline & 5 & 0.922 & 22.287 & $* * *$ & & \\
\hline \multirow{4}{*}{ US } & 1 & 0.919 & & & \multirow{4}{*}{0.896} & \multirow{4}{*}{0.682} \\
\hline & 2 & 0.91 & 21.592 & $* * *$ & & \\
\hline & 3 & 0.88 & 19.844 & $* * *$ & & \\
\hline & 4 & 0.834 & 17.5 & $* * *$ & & \\
\hline \multirow{4}{*}{ IN } & 1 & 0.903 & & & \multirow{4}{*}{0.908} & \multirow{4}{*}{0.711} \\
\hline & 2 & 0.955 & 24.276 & *** & & \\
\hline & 3 & 0.924 & 22.153 & $* * *$ & & \\
\hline & 4 & 0.859 & 18.417 & $* * *$ & & \\
\hline
\end{tabular}

\subsection{Discriminant Validity Test}

Discriminant validity means that there should be a clear difference between the measured values of different constructs, and the correlation between latent variables obtained when measuring different constructs should be less. The high correlation between latent variables means low discrimination between two configuration variable constructs, and thus there is no discriminant validity between latent variables. In order to test discriminant validity, this study used a method of determining that there is discriminant validity between variables if the square root of average variance extracted value of measurement variables is higher than the correlation between construct variables. [Table 4] represents correlation matrix between each configuration variable construct as follows, and since the square root of AVE obtained from each variable is higher than the correlation of each variable, it was confirmed that there is no issue with discriminant validity between configuration variable constructs.

Table 4. Convergent Validity Analysis

\begin{tabular}{|l|c|c|c|c|c|c|c|c|c|}
\hline & PE & TI & PS & RE & EX & AS & PR & US & IN \\
TI & 0.771 & & & & & & & & \\
PS & 0.385 & 0.783 & & & & & & & \\
\hline RE & 0.291 & 0.564 & 0.038 & 0.780 & & & & & \\
\hline EX & 0.755 & 0.28 & 0.124 & 0.358 & 0.798 & & & & \\
\hline AS & 0.754 & 0.378 & 0.232 & 0.326 & 0.729 & 0.798 & & & \\
\hline PR & -0.067 & 0.038 & -0.11 & 0.009 & -0.161 & -0.103 & 0.789 & & \\
\hline US & 0.478 & 0.366 & 0.265 & 0.453 & 0.482 & 0.602 & -0.184 & 0.826 & \\
\hline IN & 0.486 & 0.356 & 0.235 & 0.462 & 0.534 & 0.604 & -0.338 & 0.681 & 0.843 \\
\hline
\end{tabular}

\subsection{Structural Equation Model Fitness Test}

Model fitting is used to figure out how well the model built by a researcher fits data and is also called model testing. Hair et. al., (2010) recommends $\chi^{2}$, CFI, TLI, SRMR and RMSEA, GFI, TLI, CFI, and the like as the standard for determining goodness and lack of model fitness. 
Table 5. The Result of Model Fitness Test

\begin{tabular}{|c|c|c|c|}
\hline \multicolumn{2}{|c|}{ Fit indices } & Indicator & Desirable \\
\hline \multirow{6}{*}{$\begin{array}{l}\text { Absolute fit } \\
\text { index }\end{array}$} & $\begin{array}{l}x^{2}(C M I N) p \\
x^{2}(C M I N) / d f\end{array}$ & $\begin{array}{l}1093.232 \\
(\mathrm{P}=0.000) \\
1.938\end{array}$ & $\begin{array}{l}\mathrm{p} \leqq 0.05^{\sim} 0.10 \\
1.0 \leqq \mathrm{CMIN} / \mathrm{df} \leqq 2.0 \sim 3.0\end{array}$ \\
\hline & RMSEA & 0.067 & $\leqq 0.05^{\sim} 0.08$ \\
\hline & RMR & 0.062 & $\leqq 0.08$ \\
\hline & GFI & 0.789 & $\geqq 0.8^{\sim} 0.9$ \\
\hline & AGFI & 0.751 & $\geqq 0.8 \sim 0.9$ \\
\hline & PGFI & 0.668 & $\geqq 0.5^{\sim} 0.6$ \\
\hline \multirow{3}{*}{$\begin{array}{l}\text { Incremental } \\
\text { Fit index }\end{array}$} & $\mathrm{NFI}$ & 0.864 & $\geqq 0.8 \sim 0.9$ \\
\hline & NNFI(TLI) & 0.920 & $\geqq 0.8 \sim 0.9$ \\
\hline & CFI & 0.929 & $\geqq 0.8^{\sim} 0.9$ \\
\hline $\begin{array}{l}\text { Parsimony } \\
\text { Fit index }\end{array}$ & $\begin{array}{l}\text { PNFI } \\
\text { PCFI }\end{array}$ & $\begin{array}{l}0.774 \\
0.831\end{array}$ & $\begin{array}{l}\geqq 0.6 \\
\geqq 0.5^{\sim} 0.6\end{array}$ \\
\hline
\end{tabular}

\subsection{Research model verification}

A path analysis was conducted in order to check the influence level in hypotheses of this study, and six of nine were selected and three hypotheses were rejected. The above hypothesis verification results are summarized in Figure 2 and Table 6 . The standardized regression weight considering relative importance is used to find relatively more effective independent variables. The standard error (S.E.) means accuracy (stability) of the parameter. It is determined whether to select a hypothesis based on C.R. (critical ratio) of \pm 1.96 or more and P-value of 0.05 or less.

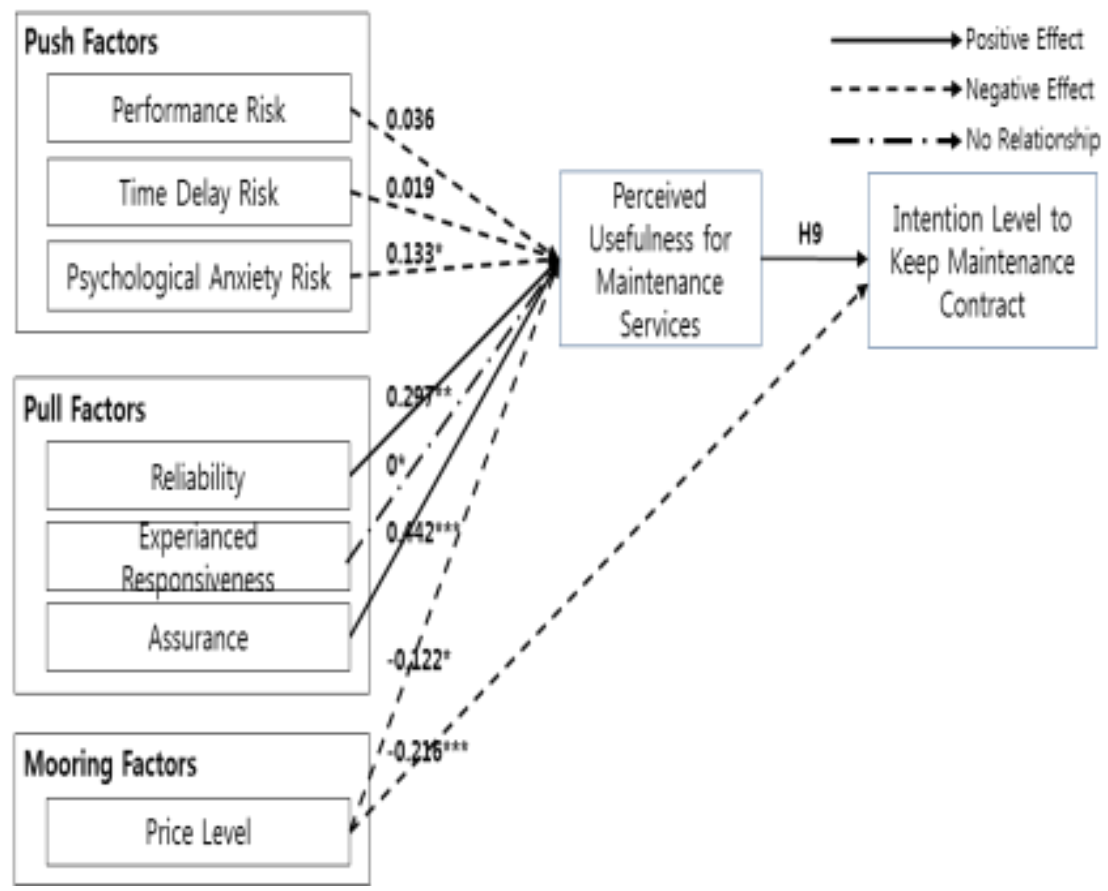

Figure 2. The Result of Hypothesis Test 
Table 6. The Result of Path Analysis

\begin{tabular}{|c|c|c|c|c|c|c|}
\hline \multirow{2}{*}{\multicolumn{2}{|c|}{$\begin{array}{c}\text { Hypothesis } \\
\text { B- }\end{array}$}} & \multirow{2}{*}{$\begin{array}{l}\text { Standardized } \\
\text { Estimate }\end{array}$} & \multirow{2}{*}{ S.E. } & \multirow{2}{*}{ C.R } & \multirow{2}{*}{ P-value } & \multirow{2}{*}{ Results } \\
\hline & & & & & & \\
\hline \multirow{7}{*}{ US } & PE & 0.036 & 0.132 & 0.334 & 0.738 & $X$ \\
\hline & TI & 0.019 & 0.066 & 0.258 & 0.796 & $X$ \\
\hline & PS & 0.133 & 0.056 & 2.334 & 0.02 & $\mathrm{O}$ \\
\hline & RE & 0.297 & 0.081 & 4.027 & $* * *$ & $\mathrm{O}$ \\
\hline & EX & 0 & 0.116 & -0.003 & 0.998 & $X$ \\
\hline & $\mathrm{AD}$ & 0.442 & 0.129 & 4.229 & $* * *$ & $\mathrm{O}$ \\
\hline & PR & -0.122 & 0.039 & -2.159 & 0.031 & $\mathrm{O}$ \\
\hline \multirow{2}{*}{$\mathbf{I N}$} & PR & -0.216 & 0.036 & -4.01 & $* * *$ & $\mathrm{O}$ \\
\hline & US & 0.659 & 0.058 & 11.051 & $* * *$ & $\mathrm{O}$ \\
\hline
\end{tabular}

As the result of verifying research hypotheses, it was found that psychological anxiety positively influences perceived usefulness of maintenance service in terms of push factors, and thus the hypothesis of negative influence was rejected. It was found that the performance risk and time delay risk don't influence perceived usefulness of maintenance service. The reliability and assurance have a valid influence on the perceived usefulness of maintenance service in terms of pull factors, but the experienced responsiveness does not have a valid influence to the perceived usefulness of maintenance service. Mooring factors perspective, it was found that price level has a valid influence to the perceived usefulness of maintenance service and intention level to keep maintenance service contract.

\subsection{Moderating Effect Analysis}

The moderating effect means that the level and direction of the relation between dependent variables and independent variables change according to the third variable. The third variable is called a moderating variable. The moderating variable is the third dependent variable affecting the relation between independent variables and dependent variables. Generally, the moderating variable is characterized by not significantly changing as time advanced. The difference between groups was individually confirmed through pairwise parameter comparison as the analysis method, and it is determined whether there is the difference between groups by critical ratios for differences between parameters (Z-statistics).

Table 7. Emotion for Audit Resistance Group Hypothesis

\begin{tabular}{|c|c|c|c|c|}
\hline \multirow{3}{*}{$\begin{array}{c}\text { Dependent } \\
\text { Variable }\end{array}$} & \multirow{3}{*}{$\begin{array}{c}\text { Independent } \\
\text { variable }\end{array}$} & \multicolumn{2}{|c|}{ Group } & \multirow{3}{*}{$\begin{array}{c}\text { Critical Ratio } \\
\text { for } \\
\text { Differences } \\
\text { Between } \\
\text { Parameters }\end{array}$} \\
\hline & & $\begin{array}{c}\mathbf{A} \\
(n=169)\end{array}$ & $\underset{(n=41)}{B}$ & \\
\hline & & $\begin{array}{l}\text { standardized } \\
\text { Estimate }\end{array}$ & $\begin{array}{l}\text { standardized } \\
\text { Estimate }\end{array}$ & \\
\hline \multirow{4}{*}{$\mathbf{P E}$} & PS & 0.104 & $0.143^{*}$ & $\begin{array}{l}0.186 \\
\text { (No difference) }\end{array}$ \\
\hline & RE & $0.317 * * *$ & -0.207 & $\begin{array}{l}-2.140^{*} \\
\text { (Difference) }\end{array}$ \\
\hline & AS & $0.582 * * *$ & -0.224 & $\begin{array}{l}-2.540 * * \\
\text { (Difference) }\end{array}$ \\
\hline & PR & -0.101 & -0.079 & $\begin{array}{l}0.238 \\
\text { (No difference) }\end{array}$ \\
\hline \multirow{2}{*}{$\mathbf{I N}$} & PR & $-0.190 * *$ & $-0.322 * *$ & $\begin{array}{l}-0.422 \\
\text { (No difference) }\end{array}$ \\
\hline & $\mathrm{PE}$ & $0.649 * * *$ & $0.666 * * *$ & $\begin{array}{l}-0.667 \\
\text { (No difference) }\end{array}$ \\
\hline
\end{tabular}


In case of enterprise using ERP software, the intention level to keep maintenance contract can be different according to resistance emotion for license audit. Therefore, the difference between groups was analyzed by dividing into 169 people of group A (having influence) and 41 people of group B (having no influence) to test the possibility of difference in expected perceived risk, service quality, and price level. As the result of confirmation applying statistical significance level DBP \pm 1.96 , it was confirmed that group A influenced by resistance against audit accepts the influence of reliability on the perceived usefulness of maintenance service more sensitively. Also, the influence of the confidence on the perceived usefulness of maintenance service is accepted more sensitively than reliability.

Table 8. Sales Revenue Group Hypothesis

\begin{tabular}{|c|c|c|c|c|}
\hline \multirow{3}{*}{$\begin{array}{c}\text { Dependent } \\
\text { Variable }\end{array}$} & \multirow{3}{*}{$\begin{array}{c}\text { Independent } \\
\text { variable }\end{array}$} & \multicolumn{2}{|c|}{ Group } & \multirow{3}{*}{$\begin{array}{c}\text { Critical Ratio } \\
\text { for } \\
\text { Differences } \\
\text { Between } \\
\text { Parameters }\end{array}$} \\
\hline & & $\underset{(n=105)}{A}$ & $\underset{(n=105)}{B}$ & \\
\hline & & $\begin{array}{l}\text { standardized } \\
\text { Estimate }\end{array}$ & $\begin{array}{l}\text { standardized } \\
\text { Estimate }\end{array}$ & \\
\hline \multirow{4}{*}{ PE } & PS & 0.008 & $0.275^{* * *}$ & $\begin{array}{l}2,268^{*} \\
\text { (Difference) }\end{array}$ \\
\hline & $\mathrm{RE}$ & $0.342 * *$ & $0.341 * * *$ & $\begin{array}{l}-0,609 \\
\text { (No difference) }\end{array}$ \\
\hline & AS & 0.247 & $0.475 * * *$ & $\begin{array}{l}1,232 \\
\text { (No difference) }\end{array}$ \\
\hline & PR & $-0.257 * *$ & 0.025 & $\begin{array}{l}2.568 * * \\
\text { (Difference) }\end{array}$ \\
\hline \multirow{2}{*}{$\mathbf{I N}$} & PR & $-0.233 * * *$ & $-0.201 * * *$ & $\begin{array}{l}0.588 \\
\text { (No difference) }\end{array}$ \\
\hline & PE & $0.651 * * *$ & $0.669 * *$ & $\begin{array}{l}-0.210 \\
\text { (No difference) }\end{array}$ \\
\hline
\end{tabular}

In case of enterprise using ERP software, the intention level to renew maintenance contract can be different according to the sales volume. Therefore, the difference between groups was analyzed by dividing into 105 companies of group A (one trillion or less) and 105 companies of group B (one trillion or more) to test possibility of difference in expected perceived risk, service quality, and price level. As the result of confirmation applying statistical significance level DBP \pm 1.96 , it was confirmed that the companies with sales of one trillion or more accepts the influence of psychological anxiety on perceived usefulness of maintenance service more sensitively. In addition, it was found that the influence of price level on perceived usefulness of maintenance service is accepted more sensitively than psychological anxiety.

\section{Conclusion}

Compare to the situation in the real business world, the data analysis results are summarized as follows. Firstly, the aspect of push factors related to this research result briefly shows reality of enterprise don't want to trying to update S/W taking a risk for improving functions of an ERP system which has less performance risk possibility and stably operated in empirical manners. Secondly, summarizing the aspect of pull factors, this research result shows that reliability and confidence positively affect perceived usefulness of maintenance service. However, it was found that the ERP venders' responsiveness experienced by ERP system administrator does not influence perceived usefulness of 
maintenance service, and it means that the venders' technical support response level is lower than the level expected by the ERP system administrator when he requests technical support service to vendor. Thirdly, considering the aspect of mooring factors, the maintenance price of major foreign-made ERP S/W license is generally $22 \%$ of purchased license price. It is implied that this maintenance price policy is higher than the price level expected by the Korean enterprise introducing foreign-made ERP systems, and there is difference in the point of view between ERP venders and enterprise about policy of maintenance. Therefore, additional researches about proper price level of maintenance are needed. To receive maintenance service from vendor, the enterprise should provide their system data in advance and grant permission so that vender can remote access to enterprise' ERP system. The enterprise' worries and distrust is vendor's misuse of system data. Moderating effect perspective, negatively affect perceived usefulness of maintenance service as the side effect of audit. Therefore, the result implies that ERP venders' license audit skill and approach should be enhanced to be recognized as a useful instrument which is acceptable by enterprise and used in receiving a proper management guide about number of user. Also, since the enterprise had sales of 1 trillion or more generally has bigger management areas using ERP compared to enterprise having sales of 1 trillion or less, the maintenance cost proportionally increases as introducing more ERP licenses, and thus the enterprise having sales of 1 trillion or more is more sensitive to maintenance cost. Therefore, it is necessary to consider developing various marketing components for enterprise paying maintenance fee in order to build a win-win relationship between enterprise and venders and continuously renew the maintenance contracts. ERP S/W maintenance contract and commercial perspective, it was found that enterprise are not satisfying vendor's responsiveness and price level. Accordingly, the verified parts in this study can be used to establish or complement maintenance strategy to improve customer satisfaction. Furthermore, differentiated goal and execution are necessary to enhance enterprise' satisfaction by utilized high-quality maintenance service and maintenance value.

\section{Acknowledgment}

This paper is a revised and expanded version of a paper "A Study on the Major Factors Affecting Intention Level to Keep to Existing Foreign ERP S/W Maintenance Contract" Presented at [13th International Convergence Workshop, Jeju National University and 8.20 22].

\section{References}

[1] D. A. and R. R. and Todd, P. A. "Perceived Usefulness, Ease of Use, and Usage of Information Technology: A replication". MIS Quarterly, vol. 16, no. 2, (1992), pp. 227-247.

[2] Lientz, B. and swanson, E. "Software Maintenance Management" Addison-Wesley, (1980).

[3] Bansal, H. S. and Shirley, F. T. "Migrating to new service Prividers: toward a Unifying Framework of Consumers' Switching Behaviors". SAGE Journal, vol. 33, no. 1, (2005), pp. 96-155

[4] Lewis, G. J. "Human migration: a geographical perspective". (1982).

[5] Bagozzi, R. P. and Warshaw, P. R. "User Acceptance of Computer Technology: A comparison of Two Theoretical Models". vol. 10, no. 3, (1989), pp.982-1003.

[6] Davis, F. D. "Perceived usefulness, perceived ease of use, and user acceptance of information technology". MIS quarterly, vol. 13, no. 3, (1989), pp. 319-340.

[7] Crespo, A. H., del Bosque, I. R., \& de los Salmones Sanchez, M. G. "The influence of Perceived risk on Internet shopping behavior: a multidimensional perspective". Journal of Risk Research, vol. 12, no. 2, (2009), pp. 259-277.

[8] Pitt, L. F., Watson, R. T., and Kavan, C. B. "Service quality: a measure of information systems effectiveness". MIS quarterly, vol. 19, no. 2, (1995), pp. 173-187.

[9] Agarwal, R. and Karahanna, E. "Time Flies When You're Having Fun: Cognitive Absorption and Beliefs about Information Technology Usage”. MIS Quarterly, vol. 24, no. 4, (2000), pp. 665-694.

[10] Cox, D. F. "Risk Taking and Information Handling in Consumer Behavior". Harvard Business Review, (1967).

[11] Lokesh Veeramacheneni, "Information Security Risk Analysis Methids: AHP and Fuzzy Comprehensive Method”,Asia-pacific Journal of Convergent Research Interchange vol. 1, no. 2, June (2015), pp. 19-24. 
[12] Jae Yoon Lee and Lahari Kolasani, "Security Based Network for Health Care System", Asia-pacific Journal of Convergent Research Interchange, vol. 1, no. 1, March (2015), pp. 1-6.

[13] Su Min Shin and Sk. Uroosa, "Predicting Software Reliability Using Particle SWARM Optimization Technique", Asia-pacific Journal of Convergent Research Interchange, vol. 1, no. 3, September (2015), pp. 17-30.

[14] Mounica Durba, "Risk Assessment of Information System", Asia-pacific Journal of Convergent Research Interchange, vol. 1, no. 3, September (2015), pp. 31-40.

[15] Ju Chan Na and G. Pavan Kumar, "Quality of Service in Meta Cloud", Asia-pacific Journal of Convergent Research Interchange, vol. 1, no. 3, September (2015), pp. 53-57.

[16] V. Bhavana, "Data Security in Cloud environments", Asia-pacific Journal of Convergent Research Interchange, vol. 1, no. 4, December (2015), pp. 25-31.

[17] Vaddempudi Srinidhi, "Classification of User Behaviour in Mobile Internet", Asia-pacific Journal of Convergent Research Interchange, vol. 2, no. 2, June (2016), pp. 9-18.

\section{Authors}

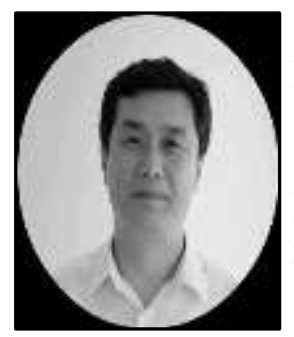

Jeong Keun Park, received his MS and Ph.D. in IT Policy Management from Soongsil University, Seoul, Korea. He worked for SAP Korea as a Head of Maintenance Go To Market, Oracle Korea as a support sales senior manager and he is IT advisor for Department of Non-Formal Education, Ministry of Education and Sports, Laos. His research focuses on the maintenance and support service of global companies-made software.

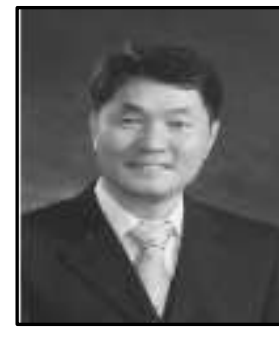

Kyeong-Seok Han, received his bachelor's degree of Education (1979) and master's degree of Management (1984) in Seoul National University, and doctor's degree of MIS in Purdue University, USA (1989). He was a professor of University of Houston. Now he is a professor in the Dept. of Management, Soongsil University, Seoul, Korea. His research interests focus on Technical MIS, Digital Economy, Agent-Eased Simulation, Web Programming, ERP.

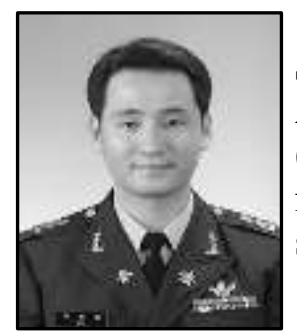

Seong Ho Kim, received Ph.D. in IT Policy Management from Soongsil University, Seoul, Korea. He is lieutenant Colonel of Army and works in the field of financial management in the DAPA (Defense Aquisituon Program Administration). His research focuses on the R\&D of defense weapon system and related legal systems. 
International Journal of Advanced Science and Technology

Vol.115 (2018) 